\title{
PHYSICAL PROPERTIES OF THE WOOD Pinus caribaea var. caribaea, Pinus caribaea var. hondurensis AND Pinus oocarpa for pencil production
}

\author{
Pedro Lício Loiola ${ }^{1 *}$, Ricardo Jorge Klitzke ${ }^{1}$, Márcio Pereira da Rocha ${ }^{1}$, Graziela Baptista Vidaurre ${ }^{2}$ \\ ${ }^{1 *}$ Federal University of Paraná, Graduate Program in Forest Engineering, Curitiba, Paraná, Brazil - pedrlicio@ hotmail.com; \\ rjkklitzke@gmail.com; mprocha01@gmail.com \\ ${ }^{2}$ Federal University of Espírito Santo, Graduate Program in Forest Sciences, Jeronimo Monteiro, Espírito Santo, Brazil - \\ grazividaurre@gmail.com
}

Received for publication: 02/09/2019 - Accepted for publication: 10/12/2019

\begin{abstract}
Resumo
Propriedades físicas das madeiras de Pinus caribaea var. caribaea, Pinus caribaea var. hondurensis e Pinus oocarpa para produção de lápis. O comportamento da propriedade física da madeira é importante para a sua utilização no setor industrial. A manufatura de produção de lápis requer matéria-prima com massa específica baixa e com elevada estabilidade dimensional. Este estudo teve por objetivo avaliar as propriedades físicas de massa específica básica, assim como, a retratibilidade das madeiras de Pinus caribaea var. caribaea de 14 anos, Pinus caribaea var. hondurensis de 25 anos e Pinus oocarpa de 35 anos, nos sentidos medula-casca em três classes de diâmetro. Todas as espécies são provenientes de povoamentos florestais localizados na região do Cerrado Brasileiro. A madeira de P. oocarpa teve a maior massa específica básica, enquanto o P. caribaea var. caribaea apresentou o menor valor. Quanto a estabilidade dimensional, o P. caribaea var. caribaea e P. oocarpa tiveram comportamentos semelhantes para a contração volumétrica e ao avaliar o coeficiente de anisotropia da madeira a espécie de $P$. caribaea var. caribaea teve maiores valores de coeficiente de anisotropia, no entanto, todos os pinus tropicais estudados, se qualificam como matéria-prima para a indústria de lápis, sendo uma alternativa as espécies tradicionalmente utilizadas.

Palavras-chave: Qualidade da madeira. Massa específica. Estabilidade dimensional. pinus tropical. Lápis de madeira.
\end{abstract}

\begin{abstract}
The behavior of the physical properties of wood is important for its use in the industrial sector. Manufacturing for pencil production requires raw material with low specific mass and high dimensional stability. The objective of this study was to evaluate the properties of the physical specific basic mass properties, anhydrous and green, as well as the retractability of the 14 years old Pinus caribaea var. caribaea, 25 years old Pinus caribaea var. hondurensis and 35 years old Pinus oocarpa in the medulla sense of the bark, base and top of the trees. All species come from the Brazilian Cerrado region afforestation. As for dimensional stability, the Pinus caribaea var. caribaea and Pinus oocarpa had similar behaviors to the volumetric contraction, when evaluating the coefficient of anisotropy of wood species of Pinus caribaea var. caribaea had higher values of anisotropy coefficient, however, all tropical pine studied, qualify as a raw material for the pencil industry, being an alternative species traditionally used.
\end{abstract}

Keywords: Quality of wood. Specific gravity. Dimensional stability. Tropical pine. Wood pencil.

\section{INTRODUCTION}

Among the various species of wood and of economic interest worldwide is Pinus, being used as a raw material for the forest-based industry. Due to the rapid growth of homogeneous Brazilian forest stands destined to the manufacture of solid wood products, the use of increasingly young trees is more and more frequent, which can compromise their formation and constitution and can compromise its formation and constitution, such as its anatomical structure, chemical composition and physical properties (VIDAURRE et al., 2013, BRAZ et al., 2014).

The properties of the wood may vary depending on the planting region (quality of site), age, growth rate and type of wood (juvenile or adult wood). The physical properties of wood of various species change according to the growth radius of the tree and the portion of wood corresponding to the first growth rings; features thinner cell walls, shorter tracheids, characterizing differences between juvenile and adult wood, according to reports by Juízo et al. (2015).

The knowledge of the behavior of the dimensional variations of the wood offers technical subsidies for the behavior of the raw material in its use in service. The relations between physical properties and the water-wood ratio are of fundamental importance for a more efficient use of wood, as well as the level of acceptable quality for the manufactured product (PAES et al., 2013; LOIOLA et al., 2019). For example, the manufacture of pencils, whose problems of dimensional instability, provide rework on the product, which has benefit throughout the production chain. The occurrences of wood warps are related to dimensional variations and are caused by the

FLORESTA, Curitiba, PR, v. 51, n. 2, p. 354-362, abril/jun 2021

Loiola, P. L. et.al.

ISSN eletrônico 1982-4688

DOI: $10.5380 /$ rf.v51 i2. 68955 
difference between the anatomical contractions of the wood, as well as the presence of juvenile wood (PAES $e t$ $a l ., 2013$ ). Vidaurre et al. (2013) also add that the compression wood is characterized by a higher content of lignin and less cellulose, which can influence the hygroscopicity of the wood, since lignin is a more hydrophobic component than cellulose molecules.

In this context, Trianoski et al. (2013), Paes et al. (2013) and Juízo et al. (2015) have studied the physical properties for being easy to determine and one of the main criteria for assessing the quality of wood, which can be related to the behavior of the final product for the pencil manufacturing industry. Therefore, this work evaluated the physical properties of specific mass as well as the shrinkage of 14 years old Pinus caribaea var. caribaea, 25 years old Pinus caribaea var. hondurensis and 35 years old Pinus oocarpa, in the medulla-bark directions in 3 diameter classes for the production of pencils.

\section{MATERIAL AND METHODS}

\section{Characterization of the material}

Two species of Pinus caribaea (P. caribaea var. caribaea and P. caribaea var. hondurensis) and one species of Pinus oocarpa were studied. The 14 years old $P$. caribaea var. caribaea comes from a forest massif belonging to the company Duratex S.A., located in the city of Nova Ponte-MG $\left(19.1466^{\circ} \mathrm{S}, 47.6784^{\circ} \mathrm{W}\right)$. The 25 years old $P$. caribaea var. hondurensis comes from a forest massif belonging to the company A.W. Faber-Castell S.A., located in the city of Prata-MG $\left(19.3100^{\circ} \mathrm{S}, 48.9277^{\circ} \mathrm{W}\right)$. The 35 years old $P$. oocarpa comes from a massive forest belonging to the company Vale do Rio Grande Reflorestamento Ltda, located in the city of Catalão-GO $\left(18.1661^{\circ} \mathrm{S}, 47.9445^{\circ} \mathrm{W}\right)$.

For the physical characterization of the studied wood of the species of $P$. caribaea var. caribaea and $P$. caribaea var. hondurensis, the trees were harvested and cut to a length of $2.40 \mathrm{~m}$ and segregated into three diametric classes: class $1(14.0$ to $18.0 \mathrm{~cm})$, class $2(18.1$ to $25.0 \mathrm{~cm})$ and class $3(25.1$ to $38.0 \mathrm{~cm})$, in the log yard of the company A.W. Faber-Castell. As for the species of $P$. oocarpa, the logs were also cut to a length of $2.40 \mathrm{~m}$ and segregated in the yard of the Vale do Rio Grande Reflorestamento Company, located in the city of CatalãoGO.

The log splitting of P. caribaea var. caribaea and P. caribaea var. hondurensis was carried out at the sawmill of AW Faber-Castell, located in the city of Prata-MG, where the main splitting occurred in a twin-axed circular saw, forming semi-blocks and then blocks, also in a twin-axed circular saw. The log splitting of P. oocarpa was carried out in the sawmill belonging to Vale do Rio Grande Reflorestamento, where the main splitting took place in a semi-circular band saw, forming the semi-block and later, block in a twin-axis circular saw. The cut models for both companies are the same and for each diameter class the companies use specific cut models, producing blocks of different dimensions in width and thickness. In order to standardize for each diameter class, the same dimensions of the blocks produced were always used for the physical characterization of contraction and specific density of the wood (Table 1).

Tabela 1. Caracterização física da madeira de $P$. caribaea var. caribaea, $P$. caribaea var. hondurensis e $P$. oocarpa Table 1. Physical characterization of wood from P. caribaea var. caribaea, $P$. caribaea var. hondurensis and $P$. oocarpa

\begin{tabular}{cccc}
\hline Diametric class & \multicolumn{2}{c}{ Block dimensions } & $\begin{array}{c}\text { Physical characterization of } \\
\text { wood }\end{array}$ \\
\cline { 2 - 3 } Class 1 & Width $(\mathrm{mm})$ & Thickness $(\mathrm{mm})$ & 84 \\
Class 2 & 120 & 84 & $\begin{array}{l}\text { Close to the bark } \\
\text { Close to the medulla }\end{array}$ \\
Class 3 & 165 & 84 & $\begin{array}{l}\text { Close to the bark } \\
\text { Close to the medulla }\end{array}$ \\
\hline
\end{tabular}

Of the blocks used for the physical characterization of the wood, the region close to the bark and close to the medulla was identified. These were sectioned in half in their thickness (parallel to the growth rings), and in this way, two predominant regions of samples were obtained (close to the medulla and close to the bark).

\section{Physical properties of wood}

The determination of the physical properties of basic, anhydrous $(0 \%)$ and green specific mass and the tangential, radial and volumetric contractions of the species of $P$. caribaea var. caribaea, $P$. caribaea var. hondurensis and P. oocarpa were carried out according to the COPANT - 461 (1972). For this purpose, 80 repetitions were used for each treatment evaluated, totaling 480 samples in the dimensions of $25 \times 25 \times 100 \mathrm{~mm}$ (radial $\mathrm{x}$ tangential $\mathrm{x}$ longitudinal). To determine the dry weight, the samples were placed in a forced ventilation

FLORESTA, Curitiba, PR, v. 51, n. 2, p. 354-362, abril/jun 2021.

Loiola, P. L. et.al. 
oven at a temperature of $103 \pm 2{ }^{\circ} \mathrm{C}$, until they were completely dry. For greater control of drying, the loss of mass of the specimens was monitored to constant mass.

The contractions of the wood were considered as an index of dimensional stability determined for each of the orientation planes (radial, tangential and volumetric) according to their dimensions, observed when the wood was in the green state and for the dry condition ( $0 \%$ humidity), associated with the anisotropy coefficient for each region of the log evaluated.

\section{Analysis and evaluation of results}

For the analysis and evaluation of the results of dimensional stability tests of tropical pine woods, a completely randomized design was used. For the analysis and evaluation of the results, an electronic spreadsheet and statistical program (Minitab®) were used.

For the factors and interaction detected as significant by the F test $(\mathrm{p} \leq 0.05)$, the Tukey test $(\mathrm{p} \leq 0.05)$ was used, with first tests of normality of data and the homogeneity Bartlett's test variances between treatments. When necessary to homogenize the variances, the data were transformed into arcsen [root (loss of mass/100)].

\section{RESULTS}

\section{Basic wood specific mass}

The results for the basic specific mass, anhydrous and green for the studied tropical pine species are in

Tabela 1. Valores referentes a massa específica básica, anidra e verde da madeira das espécies de $P$. caribaea var. caribaea, $P$. caribaea var. hondurensis e $P$. oocarpa

Table 2. Values referring to the basic, anhydrous and green specific mass of the species of $P$. caribaea var. caribaea, P. caribaea var. hondurensis and P. oocarpa wood

\begin{tabular}{|c|c|c|c|}
\hline Species & $\begin{array}{c}\text { Basic specific mass } \\
{\left[\mathrm{g} \cdot \mathrm{cm}^{-3}\right]}\end{array}$ & $\begin{array}{c}\text { Anhydrous specific } \\
\text { mass }(0 \%) \\
{\left[\mathrm{g} . \mathrm{cm}^{-3}\right]}\end{array}$ & $\begin{array}{c}\text { Green specific mass } \\
{\left[\mathrm{g} \cdot \mathrm{cm}^{-3}\right]}\end{array}$ \\
\hline Pinus caribaea var. caribaea & $\begin{array}{c}0.344 \mathrm{a} \\
(0.04 ; 12.60 \%)\end{array}$ & $\begin{array}{c}0.375 \mathrm{a} \\
(0.05 ; 13.66 \%)\end{array}$ & $\begin{array}{c}0.891 \mathrm{a} \\
(0.14 ; 15.70 \%)\end{array}$ \\
\hline Pinus caribaea var. hondurensis & $\begin{array}{c}0.398 \mathrm{~b} \\
(0.05 ; 12.83 \%)\end{array}$ & $\begin{array}{c}0.446 \mathrm{~b} \\
(0.08 ; 19.29 \%)\end{array}$ & $\begin{array}{c}0.922 \mathrm{~b} \\
(0.11 ; 12.32 \%)\end{array}$ \\
\hline Pinus oocarpa & $\begin{array}{c}0.463 \mathrm{c} \\
(0.06 ; 13.60 \%)\end{array}$ & $\begin{array}{c}0.514 \mathrm{c} \\
(0.07 ; 13.80 \%)\end{array}$ & $\begin{array}{c}0.935 \mathrm{~b} \\
(0.17 ; 18.53 \%) \\
\end{array}$ \\
\hline Significance fator & $575.48 *$ & $432.56 *$ & $11.72 *$ \\
\hline
\end{tabular}

Note: Values in parentheses correspond to standard deviation and coefficient of variation, respectively. Averages followed by the same lowercase letter (vertical) do not differ statistically from each other (Tukey, $\mathrm{p} \geq 0.05$ ).

\section{Variation of basic density by diametric class and log position}

The average results obtained for the basic density as a function of the diametric class for the species of $P$. caribaea var. caribaea, there is a statistical difference only for the largest class evaluated (class 3 ), in the medullabark sense. For the other diametric classes (class 1 and class 2), there was no statistical difference (TABLE 3).

Tabela 3. Massa específica básica da madeira de $P$. caribaea var. caribaea em função da classe diamétrica e posição na tora

Table 4. Specific gravity of $P$. caribaea var. caribaea wood according to the diametric class and position

\begin{tabular}{ccc}
\hline P. caribaea var. caribaea & \multicolumn{2}{c}{ Basic specific mass $\left[\mathrm{g} . \mathrm{cm}^{-3}\right]$} \\
\hline Diametric class & Close to the medulla & Close to the bark \\
\multirow{2}{*}{ Class 1 } & $0.316 \mathrm{bA}$ & $0.322 \mathrm{cA}$ \\
& $(0.03 ; 10.00 \%)$ & $(0.03 ; 10.10 \%)$ \\
\hline \multirow{2}{*}{ Class 2 } & $0.347 \mathrm{aA}$ & $0.368 \mathrm{bA}$ \\
& $(0.03 ; 8.56 \%)$ & $(0.03 ; 9.13 \%)$ \\
\multirow{2}{*}{ Class 3 } & $0.325 \mathrm{bB}$ & $0.385 \mathrm{aA}$ \\
& $(0.01 ; 4.05 \%)$ & $(0.06 ; 16.60 \%)$ \\
\hline Significance factor & & $14.71 *$ \\
\hline
\end{tabular}

Values in parentheses correspond to the standard deviation and coefficient of variation, respectively. Averages followed by the same letter, uppercase horizontally or lowercase vertically, within each factor, do not differ (Tukey, p > 0.05).

The average results obtained for the basic specific mass in the medulla-bark direction for the species of Pinus caribaea var. hondurensis, there was a statistical difference in all diametric classes (TABLE 4).

Tabela 5. Massa específica básica da madeira de $P$. caribaea var. hondurensis em função da posição na tora

FLORESTA, Curitiba, PR, v. 51, n. 2, p. 354-362, abril/jun 2021.

Loiola, P. L. et.al. 
Table 6. Specific gravity of $P$. caribaea var. hondurensis wood according to the diametric class and position

\begin{tabular}{ccc}
\hline Pinus caribaea var. hondurensis & \multicolumn{2}{c}{ Basic specific mass $\left[\mathrm{g} . \mathrm{cm}^{-3}\right]$} \\
\hline Diametric class & Close to the medulla & Close to the bark \\
\hline \multirow{2}{*}{ Class 1 } & $0.376 \mathrm{aB}$ & $0.456 \mathrm{aA}$ \\
& $(0.03 ; 7.60 \%)$ & $(0.04 ; 8.85 \%)$ \\
\hline \multirow{2}{*}{ Class 2 } & $0.389 \mathrm{aB}$ & $0.432 \mathrm{bA}$ \\
& $(0.04 ; 11.44 \%)$ & $(0.05 ; 11.62 \%)$ \\
\hline \multirow{2}{*}{ Class 3 } & $0.357 \mathrm{bB}$ & $0.393 \mathrm{cA}$ \\
& $(0.03 ; 8.60 \%)$ & $(0.04 ; 10.61 \%)$ \\
\hline Significance factor & & $11.10 *$ \\
\hline
\end{tabular}

Values in parentheses correspond to the standard deviation and coefficient of variation, respectively. Averages followed by the same letter, uppercase horizontally or lowercase vertically, within each factor, do not differ (Tukey, $\mathrm{p}>0.05$ ).

The average results obtained for the basic specific mass in the medulla-bark direction; there was a statistical difference in all diametric classes (TABLE 5). Similar results were observed in both varieties of the species $P$. caribaea (caribaea and hondurensis).

Tabela 7. Massa específica básica da madeira de P. oocarpa em função da posição na tora Table 8. Specific gravity of $P$. oocarpa wood according to the diametric class and position

\begin{tabular}{|c|c|c|}
\hline Pinus oocarpa & \multicolumn{2}{|c|}{ Basic specific mass $\left[\mathrm{g} . \mathrm{cm}^{-3}\right]$} \\
\hline Diametric class & Close to the medulla & Close to the bark \\
\hline Class 1 & $\begin{array}{c}0.390 \mathrm{cB} \\
(0.02 ; 5.94 \%)\end{array}$ & $\begin{array}{c}0.427 \mathrm{bA} \\
(0.06 ; 13.95 \%)\end{array}$ \\
\hline Class 2 & $\begin{array}{c}0.434 \mathrm{aB} \\
(0.03 ; 7.20 \%)\end{array}$ & $\begin{array}{c}0.502 \mathrm{bA} \\
(0.03 ; 9.43 \%)\end{array}$ \\
\hline Class 3 & $\begin{array}{c}0.465 \mathrm{bB} \\
(0.07 ; 15.95 \%)\end{array}$ & $\begin{array}{c}0.494 \mathrm{bA} \\
(0.06 ; 11.40 \%) \\
\end{array}$ \\
\hline
\end{tabular}

Note: Values in parentheses correspond to the standard deviation and coefficient of variation, respectively. Averages followed by the same letter, uppercase horizontally or lowercase vertically, within each factor, do not differ (Tukey, $\mathrm{p}>0.05$ ).

\section{Contraction of the woods}

The average results obtained for total contractions, the species of Pinus caribaea var. caribaea showed the lowest values among the evaluated tropical pine, differing statistically from the others. However, the average anisotropy coefficient was higher than the other species of tropical pine used to make pencils. Such results may be related to the lower age for this variety of tropical pine (TABLE 6).

abela 9. Contração da madeira de $P$. caribaea var. caribaea, $P$. caribaea var. hondurensis e $P$. oocarpa Table 10. Contraction from P. Caribaea var. Caribaea, P. Caribaea var. Hondurensis and P. Oocarpa wood

\begin{tabular}{ccccc}
\hline \multirow{2}{*}{ Species } & \multicolumn{4}{c}{ Wood contraction $(\%)$} \\
\cline { 2 - 4 } & Radial & Tangential & Volumetric & $\begin{array}{c}\text { Anisotropy } \\
\text { coefficient }\end{array}$ \\
\hline \multirow{2}{*}{ Pinus caribaea var. caribaea } & $2.86 \mathrm{a}$ & $\begin{array}{c}5.39 \mathrm{a} \\
(1.01 ; 35.40)\end{array}$ & $\begin{array}{c}8.25 \mathrm{a} \\
(1.23 ; 22.75)\end{array}$ & $1.88 \mathrm{~b}$ \\
\hline \multirow{2}{*}{ Pinus caribaea var. hondurensis } & $3.90 \mathrm{~b}$ & $6.02 \mathrm{~b}$ & $9.93 \mathrm{~b})$ & $1.54 \mathrm{a}$ \\
\hline \multirow{2}{*}{ Pinus oocarpa } & $(1.19 ; 30.45)$ & $(1.73 ; 28.69)$ & $(2.55 ; 25.73)$ & $1.60 \mathrm{a}$ \\
\hline Significance factor & $3.87 \mathrm{~b}$ & $6.19 \mathrm{~b}$ & $10.07 \mathrm{~b}$ & $61.08^{*}$ \\
\hline
\end{tabular}

Values in parentheses correspond to the standard deviation and coefficient of variation, respectively. Averages followed by the same lowercase letter (vertical) do not differ statistically from each other (Tukey, $\mathrm{p}>0.05$ ).

\section{Variation of wood contraction by diameter class and log position}

For the contraction analysis of $P$. caribaea var. caribaea, it is observed that the logs with diameter from 14.0 to $25.0 \mathrm{~cm}$ (classes 1 and 2) and for the woods located close to the bark had the highest indexes (8.52 and $9.82 \%$ ). While the wood next to the bark of logs of greater diameter (class 3 ) contracted $5 \%$ less than that located close to the medulla (TABLE 7).

The contraction analysis $P$. caribaea var. hondurensis, the values obtained for the smallest diametric class (class 1) are observed the values obtained for the smaller diametric class (class 1) that the wood located near the

FLORESTA, Curitiba, PR, v. 51, n. 2, p. 354-362, abril/jun 2021.

Loiola, P. L. et.al. 
medulla provided smaller contractions $(3.32,5.37$ and $8.68 \%)$, for the radial, tangential and volumetric direction in relation to the values obtained for the wood close to the bark. However, when analyzing the anisotropic factor, it is noted that the wood located near the medulla, had the highest anisotropy coefficients, however this variation corresponds to $6.17 \%$.

As for the results obtained for the contraction of the $P$. oocarpa, it is generally noted that the species evaluated has greater dimensional stability, despite the fact that wood has the highest basic specific mass among all the tropical pine trees evaluated for pencil production (TABLE 7).

Tabela 11. Contração da madeira de $P$. caribaea var. caribaea, $P$. caribaea var. hondurensis e $P$. oocarpa em função da classe diamétrica e posição na tora

Table 12. Contraction from $P$. caribaea var. caribaea P. caribaea var. hondurensis and $P$. oocarpa wood according to the diametric class and position

\begin{tabular}{|c|c|c|c|c|c|}
\hline \multirow{2}{*}{$\begin{array}{c}\text { Pinus caribaea } \\
\text { var. caribaea }\end{array}$} & \multirow{2}{*}{$\begin{array}{l}\log \\
\text { position }\end{array}$} & \multicolumn{3}{|c|}{ Wood contraction (\%) } & \multirow{2}{*}{$\begin{array}{l}\text { Anisotropy } \\
\text { coefficient }\end{array}$} \\
\hline & & Radial & Tangential & Volumetric & \\
\hline \multirow{2}{*}{ Class 1} & Medulla & $\begin{array}{c}2.77 \\
(0.45 ; 16.11 \%)\end{array}$ & $\begin{array}{c}4.24 \\
(0.61 ; 14.40 \%)\end{array}$ & $\begin{array}{c}7.00 \\
(0.81 ; 11.61 \%)\end{array}$ & 1.53 \\
\hline & Bark & $\begin{array}{c}2.91 \\
(0.75 ; 25.86 \%)\end{array}$ & $\begin{array}{c}5.61 \\
(1.01 ; 18.63 \%)\end{array}$ & $\begin{array}{c}8.52 \\
(1.66 ; 19.51 \%)\end{array}$ & 1.92 \\
\hline \multirow{2}{*}{ Class 2} & Medulla & $\begin{array}{c}3.51 \\
(0.77 ; 21.90 \%)\end{array}$ & $\begin{array}{c}4.99 \\
(0.94 ; 18.80 \%)\end{array}$ & $\begin{array}{c}8.50 \\
(1.37 ; 16.07 \%)\end{array}$ & 1.42 \\
\hline & Bark & $\begin{array}{c}3.17 \\
(0.86 ; 27.10 \%)\end{array}$ & $\begin{array}{c}6.66 \\
(1.19 ; 17.82 \%)\end{array}$ & $\begin{array}{c}9.82 \\
(1.64 ; 16.66 \%)\end{array}$ & 2.10 \\
\hline \multirow{2}{*}{ Class 3} & Medulla & $\begin{array}{c}2.74 \\
(1.03 ; 37.80 \%)\end{array}$ & $\begin{array}{c}4.95 \\
(0.82 ; 16.58 \%)\end{array}$ & $\begin{array}{c}7.68 \\
(1.33 ; 17.31 \%)\end{array}$ & 1.81 \\
\hline & Bark & $\begin{array}{c}2.13 \\
(1.02 ; 47.74 \%) \\
\end{array}$ & $\begin{array}{c}5.10 \\
(0.94 ; 18.40 \%) \\
\end{array}$ & $\begin{array}{c}7.23 \\
(1.56 ; 21.56 \%) \\
\end{array}$ & 2.39 \\
\hline \multirow{2}{*}{$\begin{array}{l}\text { Pinus caribaea } \\
\text { var. hondurensis }\end{array}$} & \multirow{2}{*}{$\begin{array}{l}\log \\
\text { position }\end{array}$} & \multicolumn{3}{|c|}{ Wood contraction $(\%)$} & \multirow{2}{*}{$\begin{array}{l}\text { Anisotropy } \\
\text { coefficient }\end{array}$} \\
\hline & & Radial & Tangential & Volumetric & \\
\hline \multirow{2}{*}{ Class 1} & Medulla & $\begin{array}{c}3.32 \\
(1.10 ; 33.08 \%)\end{array}$ & $\begin{array}{c}5.37 \\
(1.47 ; 27.25 \%)\end{array}$ & $\begin{array}{c}8.68 \\
(2.10 ; 24.26 \%)\end{array}$ & 1.62 \\
\hline & Bark & $\begin{array}{c}4.29 \\
(1.28 ; 29.80 \%)\end{array}$ & $\begin{array}{c}6.50 \\
(1.76 ; 27.04 \%)\end{array}$ & $\begin{array}{c}10.74 \\
(2.39 ; 22.24 \%)\end{array}$ & 1.52 \\
\hline \multirow{2}{*}{ Class 2} & Medulla & $\begin{array}{c}3.21 \\
(0.91 ; 28.38 \%)\end{array}$ & $\begin{array}{c}4.47 \\
(1.17 ; 26.10 \%)\end{array}$ & $\begin{array}{c}7.68 \\
(1.94 ; 25.29 \%)\end{array}$ & 1.39 \\
\hline & Bark & $\begin{array}{c}4.99 \\
(0.99 ; 17.95 \%)\end{array}$ & $\begin{array}{c}7.75 \\
(0.81 ; 10.51 \%)\end{array}$ & $\begin{array}{c}12.73 \\
(1.45 ; 11.36 \%)\end{array}$ & 1.55 \\
\hline \multirow{2}{*}{ Class 3} & Medulla & $\begin{array}{c}3.90 \\
(1.42 ; 36.50 \%)\end{array}$ & $\begin{array}{c}4.97 \\
(1.41 ; 28.30 \%)\end{array}$ & $\begin{array}{c}8.87 \\
(2.35 ; 26.44 \%)\end{array}$ & 1.36 \\
\hline & Bark & $\begin{array}{c}4.80 \\
(0.91 ; 18.87 \%)\end{array}$ & $\begin{array}{c}6.63 \\
(1.16 ; 17.44 \%)\end{array}$ & $\begin{array}{c}11.43 \\
(1.41 ; 12.35 \%)\end{array}$ & 1.38 \\
\hline \multirow{2}{*}{ Pinus oocarpa } & Log & \multicolumn{3}{|c|}{ Wood contraction $(\%)$} & \multirow{2}{*}{$\begin{array}{l}\text { Anisotropy } \\
\text { coefficient }\end{array}$} \\
\hline & position & Radial & Tangential & Volumetric & \\
\hline \multirow{2}{*}{ Class 1} & Medulla & $\begin{array}{c}3.98 \\
(0.81 ; 26.30 \%)\end{array}$ & $\begin{array}{c}5.27 \\
(1.51 ; 28.73 \%)\end{array}$ & $\begin{array}{c}8.34 \\
(1.64 ; 19.71 \%)\end{array}$ & 1.32 \\
\hline & Bark & $\begin{array}{c}4.23 \\
(1.05 ; 24.80 \%)\end{array}$ & $\begin{array}{c}6.72 \\
(1.29 ; 19.26 \%)\end{array}$ & $\begin{array}{c}10.94 \\
(1.74 ; 15.89 \%)\end{array}$ & 1.58 \\
\hline \multirow{2}{*}{ Class 2} & Medulla & $\begin{array}{c}4.29 \\
(0.89 ; 20.65 \%)\end{array}$ & $\begin{array}{c}6.33 \\
(1.33 ; 21.06 \%)\end{array}$ & $\begin{array}{c}10.62 \\
(1.47 ; 13.84 \%)\end{array}$ & 1.48 \\
\hline & Bark & $\begin{array}{c}3.50 \\
(0.84 ; 23.96 \%)\end{array}$ & $\begin{array}{c}6.33 \\
(1.22 ; 19.35 \%)\end{array}$ & $\begin{array}{c}9.82 \\
(1.83 ; 18.60 \%)\end{array}$ & \multirow[b]{2}{*}{1.62} \\
\hline \multirow{2}{*}{ Class 3} & Medulla & $\begin{array}{c}3.32 \\
(1.10 ; 33.08 \%)\end{array}$ & $\begin{array}{c}5.37 \\
(1.47 ; 27.25 \%)\end{array}$ & $\begin{array}{c}8.68 \\
(2.10 ; 24.26 \%)\end{array}$ & \\
\hline & Bark & $\begin{array}{c}4.29 \\
(1.28 ; 29.80 \%)\end{array}$ & $\begin{array}{c}6.50 \\
(1.76 ; 27.04 \%)\end{array}$ & $\begin{array}{c}10.74 \\
(2.39 ; 22.24 \%)\end{array}$ & 1.52 \\
\hline
\end{tabular}

Note: Values in parentheses correspond to the standard deviation and coefficient of variation, respectively.

\section{DISCUSSION}

FLORESTA, Curitiba, PR, v. 51, n. 2, p. 354-362, abril/jun 2021.

Loiola, P. L. et.al. 


\section{Basic specific mass of species}

It is observed (TABLE 2), the average results obtained for the basic specific mass, in which the wood of Pinus caribaea var. caribaea presented the lowest values among the species evaluated $\left(0.344 \mathrm{~g} . \mathrm{cm}^{-3}\right)$. Such results may be related to the younger age of the tree. The specific mass is one of the properties of interest in the manufacture of pencils, since soft woods provide the feeling of comfort for sharpenability (lower torque), in addition to facilitating the stages of the productive process of machining, gluing and finishing (surface painting and printing). The differences between specific masses were $13.56 \%$ compared to $P$. caribaea var. hondurensis and $25.70 \%$ when compared to $P$. oocarpa wood.

Regarding the classification of the basic specific mass of the species studied, the woods of Pinus caribaea var. caribaea and Pinus caribaea var. hondurensis can be classified as very light woods and the wood of Pinus oocarpa as light, according to Carvalho (1996). For the manufacture of wooden pencils, the basic density must present values that characterize it as light woods, as it presents low resistance when sharpening the pencil. However, the manufactured product must have sufficient flexural strength so that the tip does not break when used in service, there is an inclination of $60^{\circ}$, as well as the graphite (lead) break caused by the force of writing and coloring (KAYGIN et al., 2015).

There is a wide range for the specific mass of the species studied, according to reports by Moraes Neto and Melo (2008) and Amorim et al. (2013). The main cause of this specific mass variation is related to the species' characteristics, wood moisture content, proportion of initial or late wood, width of growth rings, tree growth site and silvicultural tracts (KOLLMANN; CÔTÉ JUNIOR, 1968; KLITZKE, 2007; TRIANOSKI et al., 2013).

When comparing with species traditionally used for the production of pencils (cedar, gmeline and poplar), the average results obtained for the basic specific mass in this study are close to the wood of Toona ciliata (Australian cedar) reported by Pereyra et al. (2006), Albino et al. (2010) and Trianoski et al. (2014), which provided values from 0.366 to $0.422 \mathrm{~g} . \mathrm{cm}^{-3}$. For Gmelina arborea, the values obtained in the literature range from 0.432 to $0.603 \mathrm{~g} . \mathrm{cm}^{-3}$ as reported by Espinoza (2004) and Moya and Tomazello Filho (2009). The wood of Populus tremula, Kaygin et al. (2015) reported values of up to $0.400 \mathrm{~g} . \mathrm{cm}^{-3}$. In view of the basic specific mass values of the species of Toona ciliara and Gmelina arborea, tropical pine woods have the potential to be used as raw material for making pencils.

\section{Variation of basic density by diametric class and log position}

When evaluating the basic specific mass for the species $P$. caribaea var. caribaea, the wood belonging to the medullary region of the logs, there is a difference of $8.93 \%$ between the highest basic density (class 2 ) and the lowest class (class 1). As for the wood belonging to the ends of the log, the difference between the highest basic specific mass (class 3) and the lowest (class 1) was 16.36\% (TABLE 3). In production processes, the standardization of the finished product is a way of maintaining the competitiveness of the industrial segment, with the segregation of wood due to its location in the medulla-bark sense as a method of controlling the acceptable quality level (AQL) of the finished product. The woods close to the bark are approximately $18 \%$ denser than those close to the medulla; consequently, pencils originating in this region tend to be more resistant to sharpening. The results obtained for the basic specific mass in the medulla-bark sense in this study, are consistent with those provided by Iwakiri et al. (2010) when using the species for the production of particulate panels, obtained values of $0.405 \mathrm{~g}^{\mathrm{cm}} \mathrm{cm}^{-3}$ in his experiments. While, Trianoski et al. (2012) when assessing the stability of tropical pine wood, reported values of $0.411 \mathrm{~g} . \mathrm{cm}^{-3}$ in their studies.

For the Pinus caribaea var. hondurensis species, the wood located near the medulla is approximately $22 \%$ lighter than the wood located at the ends of the trunk. Like, P. caribaea var. caribaea, the hondurensis variety has distinct technological properties among the pencils produced from lamellae in the outermost region, which may present greater resistance in their sharpenability (TABLE 4). This difference in basic specific mass for the outermost wood of the trunk and between the diametric classes may be related to the randomness of the sampling and the heterogeneity of the forest stand. Since the class with the smallest diameter (class 1) does not necessarily correspond to the logs belonging to the individuals' shaft, concomitantly, the class with the largest diameter (class 3 ) is not necessarily base logs in their entirety. In forest stands from seeds, there is a heterogeneity of individuals (dominant trees and dominated trees).

The values available in the literature of basic specific mass for the species of $P$. caribaea var. hondurensis vary between 0.321 to $0.531{\mathrm{~g} . \mathrm{cm}^{-3}}^{-3}$, according to studies by Aroni and Rezende (2007), Gonçalez et al. (2009) and Trianoski et al. (2012) for trees from 18 to 28 years old.

As for the Pinus oocarpa species, the average results obtained for the wood close to the medulla, there is a statistical difference between all diametric classes, increasing with the increase in the diameter of the logs. Woods originating from logs with a larger diameter (class 3 ) are $16 \%$ denser than woods belonging to the thinnest logs. As for the woods located near the bark, there was no statistical difference between the diametric classes, by the Tukey test at $95 \%$ probability (TABLE 5).

FLORESTA, Curitiba, PR, v. 51, n. 2, p. 354-362, abril/jun 2021.

Loiola, P. L. et.al. 
The $P$. oocarpa species had the highest basic specific mass $\left(0.463 \mathrm{~g} . \mathrm{cm}^{-3}\right)$ among the evaluated tropical pine used for making pencils. The values available in the literature of basic specific mass for the species of $P$. oocarpa from between 0.431 to $0.564 \mathrm{~g} . \mathrm{cm}^{-3}$, according to studies by Trianoski et al. (2012); Trianoski et al. (2013).

\section{Contraction of species}

The magnitude of contraction for all species (TABLE 6) is in agreement, according to reports by Kollmann and Côté Junior (1968) for softwood, which report variations from 2.1 to $5.1 \%$ respectively for the radial direction, 4.4 to $9.1 \%$ for the tangential direction and 6.5 to $14 \%$ for the total volumetric contraction of the wood. The dimensional variation usually occurs in wood of greater specific mass, explained by the greater quantity of wood per unit of volume (OLIVEIRA et al., 2010). This fact was evidenced for the Pinus oocarpa, which had a total contraction of $10.07 \%$ and a higher basic specific mass $\left(0.463 \mathrm{~g} . \mathrm{cm}^{-3}\right)$.

The total volumetric contraction (sum of the radial and tangential contraction), mean values of 8.25, 9.93 and $10.07 \%$, respectively for $P$. caribaea var. caribaea, $P$. caribaea var. hondurensis and $P$. oocarpa, highlighting the low values for volumetric contraction. The anisotropy coefficient (ratio between tangential and radial contraction), of the evaluated tropical pine, found values ranging from 1.54 to 1.88 , respectively for $P$. caribaea var. hondurensis and $P$. caribaea var. caribaea. The woods of $P$. caribaea var. hondurensis and $P$. oocarpa did not differ statistically according to the Tukey test at the level of 5\% probability.

For the evaluation of the dimensional stability of the wood, it must always take into account the total volumetric contraction, together with the anisotropy coefficient, as its evaluation in an isolated way does not characterize a species as being dimensionally stable. Kollmann and Côté Junior (1968) emphasize that high values of the anisotropy coefficient can come from low tangential and radial contractions, which proves to be a wood with high dimensional instability.

The dimensional movement and the differences between the radial and tangential contractions are physical properties of interest in the manufacture of pencils, since the pencil manufacturing process takes place by gluing two slides and the tolerance for bending is $0.5 \mathrm{~mm}$ along the length of the pencil. In view of the results obtained, it can be predicted that the studied tropical pine species qualify as raw material for pencils.

\section{Variation of the contraction of the wood by diametric class and position in the log}

For the Pinus caribaea var. caribaea in general (TABLE 7), the volumetric contraction rates are low, regardless of the region where the wood is located (near the medulla or the bark). The understanding of the physical property of the contraction of wood destined for the production of lamellae for the manufacture of pencils becomes important, due to the quantity of lamellae and pencils produced from a log. Because it is a product of small dimensions, each lamella is likely to produce up to ten grooves, consequently up to ten pencils.

For wood of higher diametric class (class 3), greater stability is noted for the portion close to the medulla, however, this region provided greater dimensional variation in the radial, tangential and volumetric directions. However, when evaluating the anisotropy coefficient, it is noticed that the wood near the medulla has greater dimensional stability.

For the ratio between the differences in tangential and radial contraction, it is noted that the wood located near the medulla showed the lowest values, providing greater stability than that located near the bark. This fact is related to the specific mass of this type of wood and the statements by Kollmann and Côté Junior (1968) and Oliveira et al. (2010), in which they mention that the contraction in the tangential direction oscillates around twice that occurred in the radial direction. These differences in contraction of the wood in its anatomical planes can be attributed to the constitution of the microscopic and sub-microscopic structures of the material itself, as these are arranged vertically in the radial direction in relation to the tangential direction, making the number of cell walls per volume unit to be much smaller in the radial direction.

In view of the results obtained for the volumetric contraction and the anisotropy coefficient, the wood of the 14 years old $P$. caribaea var. caribaea can be considered low in both regions of the log (medulla and bark). There are not many reports in the literature on the physical contraction properties of Pinus caribaea var. caribaea wood; however, it is necessary to compare the results obtained in this research with those reported by Trianoski $e t$ al. (2013), when studying the dimensional stability of tropical pine species, reported values of 2.62, 6.01 and $8.69 \%$ respectively for the radial, tangential and volumetric directions and an anisotropic coefficient of 2.45.

As for the Pinus caribaea var. hondurensis species, similar results are perceived when evaluating the second diametric class in which, woods located near the medulla, have the lowest volumetric contraction indices, as well as the anisotropy coefficient. It is noticed that the Pinus caribaea hondurensis variety has desirable characteristics as a raw material for the manufacture of pencils, depending on the dimensional variation indices of the wood, combined with the anisotropy coefficient of the medullary wood, as well as for the wood located near the bark. In general, the species of $P$. caribaea var. hondurensis can be considered as stable wood according to

FLORESTA, Curitiba, PR, v. 51, n. 2, p. 354-362, abril/jun 2021.

Loiola, P. L. et.al. 
Klitzke (2007), and with a low tendency to defects in the drying process and even to sudden variations in its hygroscopic equilibrium humidity.

For wood also from the cerrado, Santos et al. (2012), found radial, tangential and volumetric contractions of $4.12,6.34$ and $10.46 \%$, respectively, and anisotropic factor of 1.54. Trianoski et al. (2013), when evaluating the dimensional stability of tropical pine species, reported values of 2.42, 5.74 and $8.95 \%$ respectively for the radial, tangential and volumetric directions and an anisotropic coefficient of 2.52. While, Gonçalez et al. (2018) found a contraction of 4.92, 6.00 and $10.86 \%$ (radial, tangential and volumetric) for wood with a higher percentage of initial wood. While, for the woods with a higher percentage of final wood, the authors reported values of 6.53 , 7.96 and $14.14 \%$ for the radial, tangential and volumetric directions of the wood.

As for the results obtained for the contraction of the $P$. oocarpa wood, it is noted in general that the species evaluated has low dimensional movement, despite the wood having the highest basic specific mass among all the tropical pine evaluated for the production of pencils. The wood belonging to the thinnest $\operatorname{logs}(\mathrm{class} 1) \mathrm{had}$ the lowest volumetric contraction rates (average of 9.64\%) as well as the anisotropy coefficient, with an average value of 1.45 . However, when evaluating the second diametric class in which, woods located close to the medulla, presented the highest volumetric contraction indexes, in comparison to the one located close to the bark for this same diametric class. For the third diametric class, the woods located close to the medulla, had the lowest volumetric contraction rates.

For the anisotropic coefficient, the species of $P$. oocarpa, according to the classification suggested by Klitzke (2007), can be considered as stable, with a tendency to a low propensity for defects in the drying process and even to sudden variations in its hygroscopic equilibrium humidity. The greater the number of ray cells, which constitute the anatomical structure of the wood, both in the direction of the medulla-bark, both along the shaft, the greater the contribution in terms of the restriction of the dimensional variation in the radial direction. However, other factors such as the radial dimensions of the tracheids and chemical differentiation between the radial and tangential cell walls can also be decisive factors in the influence of the anisotropy of the retractability of the wood.

The importance of understanding the characteristic of the 35 years old wood for the pencil industry occurs due to the predictability of the pencil produced, both in the region of medullary wood and in the external region of the $\log$, as well as its characteristics of warping and resistance to torque in its sharpenability. Trianoski et al. (2013), in their studies regarding the dimensional stability of the species, reported values of 2.89, 6.47 and $10.22 \%$ respectively for the radial, tangential and volumetric directions and an anisotropic coefficient of 2.45. Whereas, Cavalheiro et al. (2016), when evaluating the density relationship in the physical properties of wood contraction, found contractions of $6.47,9.89$ and $17.10 \%$ (radial, tangential and volumetric) and anisotropic coefficient of 1.53 . It appears that the results obtained by the authors were superior to those found in this research and the probable differences are associated with the aspects of age, specific mass, sampling, growth conditions and, consequently, different origins, which were not mentioned.

\section{CONCLUSIONS}

- Tropical pine woods are classified as light woods, characterizing them as raw material for pencil production.

- $\quad$ The species of $P$. caribaea var. hondurensis and P. oocarpa showed statistical difference for the basic specific mass for the woods near the bark and marrow.

- The dimensional stability of tropical pine wood meets the acceptable quality level for the manufacture of pencils.

- The tropical pine woods studied can be considered as an alternative to the species traditionally used in the pencil industry.

\section{REFERENCES}

ALBINO, V. C. S.; SÁ, V. A.; BUFALINO, L.; MENDES, L. M.; ALMEIDA, N. A. Avaliação das propriedades físico-mecânicas de painéis compensados de Toona ciliata M. Roem. var. australis. Cerne, Lavras, v. 17, p. 103$108,2010$.

AMORIM, P.G. R.; GONÇALEZ, J. C.; GONÇALVES, R.; TELES, R. F.; SOUZA, F. Ultrasound waves for assessing the technological properties of Pinus caribaea var hondurensis and Eucalyptus grandis wood. Maderas. Ciencia y Tecnología, Concepcion, v. 15, p. 2-10, 2013.

ARONI, A.S.; REZENDE, M.A. Avaliação dos índices de produtividade do híbrido do Pinus caribaea var. hondurensis x Pinus tecunumanii, no estado de São Paulo. Energia Agrícola, Piracicaba, v. 22, n.1, p. 17- 32, 2007.

FLORESTA, Curitiba, PR, v. 51, n. 2, p. 354-362, abril/jun 2021.

Loiola, P. L. et.al. 
BRAZ, R. L.; OLIVEIRA, J. T. S.; ROSADO, A. M.; VIDAURRE, G. B.; PAES, J. B.; TOMAZELLO FILHO, M.; LOIOLA, P. L. Caracterização anatômica, física e química da madeira de clones de Eucalyptus cultivados em áreas sujeitas à ação de ventos. Ciência da Madeira, Pelotas, v. 5, p. 127-137, 2014.

CARVAlHO, A. Denominações convencionais para propriedades da madeira. In: Carvalho, A. Tecnologia das indústrias da madeira III - Na2. Vol. I. Lisboa. 1996. 5p.

CAVAlHEIRO, R. S.; ALMEIDA, D. H.; ALMEIDA, T. H.; CHRISTOFORO, A. L.; LAHR, F. A. R. Density as estimator of shrinkage for some brazilian wood species. International Journal of Materials Engineering, Rosemead, v. 6, p. 107-112, 2016.

COMISSÃO PANAMERICANA DE NORMAS TÉCNICAS. COPANT 461. Determinación del peso especifico aparente. 1972. 8p.

GONÇALEZ, J.C.; SANTOS, N.; SILVA, F. G.; SOUZA, R. S.; PAULA, M. H. Growth ring width of Pinus caribaea var. hondurensis and its relationship with wood proprieties. Scientia Forestalis, Piracicaba, v. 46, p. 309-317, 2018.

GONÇALEZ, J.C.; VIEIRA, F.S.; CAMARGOS, J.A.A.; ZERBINI, N.J. Influência do sítio nas propriedades da madeira de Pinus caribaea var. hondurensis. Cerne, Lavras, v. 15, n. 2, p. 251-255, 2009.

IWAKIRI, S.; MATOS, J.L.M; PINTO, J.A.; VIANA, L.C.; SOUZA, M.M.; TRIANOSKI, R.; ALMEIDA, V.C. Produção de painéis laminados unidirecionais LVL com lâminas de Schizolobium amazonicum, Eucalyptus saligna e Pinus taeda. Cerne, Lavras, v. 16, n. 4, p. 557 - 563, 2010.

KAYGIN, B.; KAPLAN, D.; AYDEMIR, D. Paulownia tree as an alternative raw material for pencil manufacturing. BioResources, v.10, n.2, p. 3426 -3433, 2015.

KLITZKE, R. J. Secagem da madeira. In: José Tarcísio da Silva Oliveira, Nilton César Fiedler, Marcelo Nogueira. (Org.). Tecnologias aplicadas ao setor madeireiro. Visconde do Rio Branco: Suprema Gráfica e Editora Ltda, 2007, v. 1, p. 271-366.

KOLLMANN, F. E. P.; CÔTE JUNIOR, W. A. Principles of wood science and technology. New York: SpringerVerlarg, 1968. V.1, 592p.

LOIOLA, P. L.; MARCHESAN, R.; FRANCA, M. C.; JUIZO, C. G.; ROCHA, M. P.; KLITZKE, R. J. Yield of a portable sawmill and wood drying of Hovenia dulcis in conventional kiln. Revista Floresta, Curitiba, v. 49, p. 79-88, 2019.

MENDES, L. M.; IWAKIRI, S.; MATOS, J. L. M.; KEINERT JR, S.; SALDANHA, L. K. Pinus spp. na produção de painéis de partículas orientadas (OSB). Ciência Florestal, Santa Maria, v. 12, n.2, p. 135-145, 2002.

MORAES NETO, S.P.; DUBOC, E. Parâmetros genéticos da densidade básica da madeira de Pinus caribaea var. hondurensis. Boletim de Pesquisa e Desenvolvimento, n. 213, 2008, 18p.

MOYA, R.; TOMAZELLO FILHO, M. Wood density variation and tree ring demarcation in Gmelina arborea trees using X-ray densitometry. Cerne, Lavras, v. 15, p. 92-100. 2009.

OLIVEIRA, J. T. S.; TOMAZELLO FILHO, M; FIEDLER, N. C. Avaliação da retratibilidade da madeira de sete espécies de Eucalyptus. Revista Árvore, Viçosa, v.34, n.5, p. 929 - 936. 2010.

PAES, J. B.; LOIOLA, P. L.; EUFLOSINO, A. E. R.; SALVADOR, F. M.; VITORIA, J. B. Efeito de soluções salinas na estabilidade dimensional da madeira de kiri (Paulownia tomentosa). Revista Científica Eletrônica de Engenharia Florestal, Garça, v. 21, p. 72-84, 2013.

PEREYRA, O.; SUIREZS, T. M.; PITSCH, C.; BAEZ, R. Estudio de lãs propriedades físico-mecanicas y comportamiento em procesos industriales de La madera de kiri, grevílea, paraíso y toona. Revista Floresta, Curitiba, v. 36, n. 2, p. 213-223, 2006.

SANTOS, C. M. T.; DEL MENEZZI, C. H. S.; SOUZA, M. R. Properties of thermo-mechanically treated wood from Pinus caribaea var. hondurensis. BioResources, v.7, p. 1850 - 1865, 2012.

TRIANOSKI, R.; MATOS, J. L. M.; IWAKIRI, S.; PRATA, J. G. Avaliação da estabilidade dimensional de espécies de Pinus tropicais. Floresta e Ambiente, Seropédica, v. 20, p. 398-406, 2013.

TRIANOSKI, R.; MATOS, J. L. M.; IWAKIRI, S. Propriedades físicas, químicas e mecânicas da madeira de cedro australiano cultivado em Corupá, SC. Pesquisa Florestal Brasileira, Colombo, v. 34, p. 435-441, 2014.

VIDAURRE, G. B.; LOMBARDI, L. R.; NUTTO, L.; NISTAL, F. J. F.; OLIVEIRA, J. T. S.; ARANTES, M. D. C. Propriedades da madeira de reação. Floresta e Ambiente, Seropédica, v. 20, p. 1-37, 2013.

FLORESTA, Curitiba, PR, v. 51, n. 2, p. 354-362, abril/jun 2021.

Loiola, P. L. et.al. 